\title{
Pattern and predictors of mortality in necrotizing fasciitis patients in a single tertiary hospital
}

\author{
Gaby Jabbour ${ }^{1}$, Ayman El-Menyar ${ }^{2,3^{*}}$ (D), Ruben Peralta ${ }^{4}$, Nissar Shaikh ${ }^{5}$, Husham Abdelrahman ${ }^{4}$, \\ Insolvisagan Natesa Mudali ${ }^{5}$, Mohamed Ellabib ${ }^{4}$ and Hassan Al-Thani ${ }^{4}$
}

\begin{abstract}
Background: Necrotizing fasciitis (NF) is a fatal aggressive infectious disease. We aimed to assess the major contributing factors of mortality in NF patients.

Methods: A retrospective study was conducted at a single surgical intensive care unit between 2000 and 2013. Patients were categorized into 2 groups based on their in-hospital outcome (survivors versus non-survivors).

Results: During a14-year period, $331 \mathrm{NF}$ patients were admitted with a mean age of $50.8 \pm 15.4$ years and $74 \%$ of them were males Non-survivors $(26 \%)$ were 14.5 years older $(p=0.001)$ and had lower frequency of pain $(p=0.01)$ and fever $(p=0.001)$ than survivors $(74 \%)$ at hospital presentation. Diabetes mellitus, hypertension, and coronary artery disease were more prevalent among non-survivors $(p=0.001)$. The 2 groups were comparable for the site of infection; except for sacral region that was more involved in non-survivors $(p=0.005)$. On admission, non-survivors had lower hemoglobin levels $(p=0.001)$, platelet count $(p=0.02)$, blood glucose levels $(p=0.07)$ and had higher serum creatinine $(p=0.001)$. Non-survivors had greater median LRINEC (Laboratory Risk Indicator for NECrotizing fasciitis score) and Sequential Organ Failure Assessment (SOFA) scores $(p=0.001)$. Polybacterial and monobacterial gram negative infections were more evident in non-survivors group. Monobacterial pseudomonas $(p=0.01)$ and proteus infections ( $p=0.005$ ) were reported more among non-survivors. The overall mortality was $26 \%$ and the major causes of death were bacteremia, septic shock and multiorgan failure. Multivariate analysis showed that age and SOFA score were independent predictors of mortality in the entire study population.
\end{abstract}

Conclusion: The mortality rate is quite high as one quarter of NF patients died during hospitalization. The present study highlights the clinical and laboratory characteristics and predictors of mortality in NF patients.

Keywords: Necrotizing fasciitis, Predisposing factors, Presentation, Management, Mortality

\section{Background}

Necrotizing fasciitis (NF) is a rare infectious disease which is rapidly progressive and potentially fatal in nature [1]. Despite the advanced medical treatment, the rate of mortality remains as high as 24-34 \%; posing a challenge for the diagnosis and management [2]. The mortality in NF patients primarily depends upon the time of the medical and surgical interventions and extent of spread of infection to the primary site

\footnotetext{
* Correspondence: aymanco65@yahoo.com

${ }^{2}$ Clinical Research, Trauma Surgery, Hamad General Hospital, Doha, Qatar

${ }^{3}$ Clinical Medicine, Weill Cornell Medical School, Doha, Qatar

Full list of author information is available at the end of the article
}

(subcutaneous tissue, fasciae, skin or muscles) [3]. NF patients with streptococcal infection are associated with increased risk of complications and mortality (up to $80 \%$ ) [4]. There are various predisposing factors for NF such as advanced age, diabetes mellitus, peripheral vascular disease, obesity, chronic renal failure and trauma [5]. Therefore, early recognition of these predisposing factors might help in the early definitive management [6]. Moreover, early surgical debridement is a known contributor to improve outcomes in NF patients [5].

To date, the most appropriate tool for diagnosis and discrimination of NF is the LRINEC (Laboratory Risk 
Indicator for NECrotizing fasciitis score) scoring system proposed by Wong et al. [7]. It is based on laboratory parameters that are readily available for scoring in most institutions to predict survival and discriminate necrotizing from non-necrotizing infections. In addition, various predictors of mortality based on predisposing factors have been reported by different investigators. Previous studies have identified advanced age ( $>60$ years), aeromonas and vibrio infection, liver cirrhosis, cancer, hypotension, band polymorphonuclear neutrophils $(\mathrm{PMN})>10 \%$, and serum creatinine $>2 \mathrm{mg} / \mathrm{dL}$ to be independent predictors of mortality in NF cases $[8,9]$. Despite the fact that mortality depends upon the time of diagnosis, and management, the predisposing factors also play an important role in the outcome. The present study aims to determine the various predisposing and prognostic factors associated with mortality in NF patients.

\section{Methods}

All consecutive patients admitted to the surgical intensive care at Hamad General Hospital (HGH) with a diagnosis of necrotizing fasciitis were retrospectively included in this analysis between January 2000 and December 2013. Patients were categorized into 2 groups according to their hospital mortality (survivors versus non-survivors). The present study included patients for which the operative notes and or histopathological findings indicate NF. Data included age, sex, presentation and duration of symptoms, predisposing factors, risk factors, causative microbiological organisms, on-admission laboratory parameters, the Sequential Organ Failure Assessment (SOFA) and LRINEC score, number of operative debridement, length of intensive care and hospital stay, recurrence and in-hospital mortality. The anatomic site of infection was classified as extremity (upper and lower limbs), abdominal/groin, chest/breast, neck/facial, sacral and perineum. Exclusion criteria included patients not admitted in the ICU (uncomplicated mild forms of NF and were managed in the regular ward), patients with cellulitis or superficial infection not requiring aggressive debridement or antibiotics), and non-surgical patients.

The ratio of partial pressure of arterial oxygen and fraction of inspired oxygen $(\mathrm{PaO} 2 / \mathrm{FiO} 2)$, platelets count, bilirubin level, Glasgow coma score, mean arterial pressure (MAP), vasopressor use, creatinine level and urine output were used to calculate SOFA score [10]. The laboratory parameters such as C-reactive protein (CRP), WBC, hemoglobin, sodium level, creatinine concentration and glucose level were used to calculate the LRINEC score [7]. The various recorded parameters were analyzed according to the final outcome. This study was approved by the medical research center at HMC, Qatar with IRB\#14066/14.

\section{Statistical analysis}

Data were presented as proportions, median (range) or mean ( \pm standard deviation), as appropriate. Baseline demographic characteristics, laboratory findings, clinical presentation, bacteriology and predisposing factors were compared between non-survivors and survivors. Analyses were conducted using Student-t test for continuous variables and Pearson chi-square $\left(x^{2}\right)$ test for categorical variables; Fisher's exact test was used, if the expected cell frequencies were below 5. A 2-tailed $p<0.05$ was considered significant. Multivariate logistic regression analysis was performed to look for the predictors of mortality in the overall NF cohort along with the odd ratio and $95 \%$ confidence interval. Data analysis was carried out using the Statistical Package for Social Sciences version 18 (SPSS Inc, Chicago, Illinois).

\section{Results}

During the 14-year study period, a total of 331 admissions were recorded for NF; $74 \%$ were males and the mean age was $50.8 \pm 15.4$ years. Among them, 246 were survivors $(74.3 \%)$ and $85(25.7 \%)$ were non-survivors. Non-survivors were 14.5 years older $(61.6 \pm 14.3$ vs. $47 \pm 14$ years, $p=0.001$ ) than survivors and the two groups were comparable for gender. Moreover, higher proportion of Qatari nationals $(50.6 \%$ vs. $27.2 \%$; $p=$ 0.001) died due to NF as compared to non-Qatari (Arabs) (Table 1).

\section{Clinical findings}

On admission, the most common symptoms were local swelling (78\%), pain/tenderness (68\%) and fever (67\%). At presentation, non-survivors had significantly lower frequency of pain (57\% vs. $72 \% ; p=0.01)$ and fever $(48$ $\%$ vs. $73 \% ; p=0.001$ ) than survivors. The frequency of diabetes mellitus (64 \% vs. $47 \% ; p=0.007)$, hypertension (53\% vs. $29 \% ; p=0.001)$, renal impairment (30\% vs. $10 \% ; p=0.001)$, coronary artery disease $(25 \%$ vs. $11 \% ; p=0.001)$ and cerebrovascular accidents (8\% vs. $1 \% ; p=0.001$ ) were significantly higher among non-survivors as compared to survivor group. However, traumatic injuries (18 \% vs. $8 \%$; $p=0.04$ ) were observed more among survivors than non-survivors.

\section{Site of infection}

The most frequent site of infection was lower limb/thigh (53\%) followed by perineum (25\%), abdominal/groin region (11.5\%) and neck/facial region (6.3\%). Although, the 2 groups were comparable for the site of infection; sacral region had significantly higher frequency in nonsurvivors ( $4.7 \%$ vs. $0.4 \% ; p=0.005)$ than survivors. 
Table 1 Comparison of necrotizing fasciitis by outcome (survivors versus non-survivors)

\begin{tabular}{|c|c|c|c|c|}
\hline & All patients $(n=331)$ & Survivors $(n=246)$ & Non- survivors $(n=85)$ & $P^{*}$ \\
\hline Males & $246(74.3 \%)$ & $75 \%$ & $73 \%$ & 0.73 \\
\hline Age in years ${ }^{a}$ & $50.8 \pm 15.4$ & $47 \pm 14$ & $61.6 \pm 14.3$ & 0.001 \\
\hline \multicolumn{5}{|l|}{ Nationality } \\
\hline Qatari & $110(33.2 \%)$ & $27.2 \%$ & $50.6 \%$ & \multirow[t]{3}{*}{0.001} \\
\hline Non-Qatari (Arabs) & $73(22.1 \%)$ & $20.3 \%$ & $27.1 \%$ & \\
\hline Others & $148(44.7)$ & $52.4 \%$ & $22.4 \%$ & \\
\hline \multicolumn{5}{|l|}{ Symptoms } \\
\hline Swelling & 237 (78 \%) & $76.4 \%$ & $82.3 \%$ & 0.28 \\
\hline Pain/tenderness & $208(68.4 \%)$ & $72.4 \%$ & $57 \%$ & 0.01 \\
\hline Fever & $203(67 \%)$ & $73.3 \%$ & $48 \%$ & 0.001 \\
\hline \multicolumn{5}{|l|}{ Laboratory findings } \\
\hline Hemoglobin $(\mathrm{g} / \mathrm{dl})^{\mathrm{a}}$ & $11 \pm 2.7$ & $11.4 \pm 2.7$ & $10.1 \pm 2.6$ & 0.001 \\
\hline $\mathrm{WBC}(/ \mu l)^{\mathrm{a}}$ & $16.2 \pm 8.6$ & $16.4 \pm 8.6$ & $15.2 \pm 8.6$ & 0.28 \\
\hline Platelet count $(/ \mu \mid)^{b}$ & $269 \pm 201$ & $273 \pm 141$ & $230 \pm 158$ & 0.02 \\
\hline Sodium $\left(\mathrm{mmol} / \mathrm{I}^{\mathrm{a}}\right.$ & $133.5 \pm 5.6$ & $133.4 \pm 5.4$ & $133.9 \pm 6$ & 0.43 \\
\hline Serum Creatinine $(\mu \mathrm{mol} / /)^{b}$ & $97(26-1263)$ & $91(26-1189)$ & $135(26-1263)$ & 0.001 \\
\hline Serum Bilirubin $\left(\mu \mathrm{mol} / \mathrm{I}^{\mathrm{b}}\right.$ & $14.2(3-381)$ & $14(3-233)$ & $15(4-381)$ & 0.35 \\
\hline Serum Glucose $e^{a}$ & $12.0 \pm 7.8$ & $12.5 \pm 8.4$ & $10.7 \pm 5.4$ & 0.07 \\
\hline C-reactive protein ${ }^{a}$ & $221 \pm 120$ & $214 \pm 120$ & $232 \pm 120$ & 0.35 \\
\hline Procalcitonin $(<24 h)^{\mathrm{b}, \mathrm{c}}$ & $10.5(0.07-303)$ & $3.3(0.07-303)$ & $9.8(0.1-182)$ & 0.28 \\
\hline \multicolumn{5}{|l|}{ Scoring } \\
\hline SOFA ${ }^{b}$ & $9(2-21)$ & $9(2-19)$ & $12(7-21)$ & 0.001 \\
\hline LRINEC $^{\mathrm{b}}$ & $6(1-13)$ & $5(1-13)$ & $7(2-13)$ & 0.001 \\
\hline \multicolumn{5}{|l|}{ Site } \\
\hline Lower limb/Thigh & 175 (53 \%) & $53.3 \%$ & $51.8 \%$ & 0.81 \\
\hline Perineum & $81(25 \%)$ & $23.6 \%$ & $27 \%$ & 0.52 \\
\hline Abdominal/Groin & $38(11.5)$ & $10.6 \%$ & $14 \%$ & 0.37 \\
\hline Upper Limb & $13(3.9 \%)$ & $4.1 \%$ & $3.5 \%$ & 0.82 \\
\hline Neck/Facial & $21(6.3 \%)$ & $7.3 \%$ & $3.5 \%$ & 0.21 \\
\hline Chest/Breast & $8(2.4 \%)$ & $2.8 \%$ & $1.2 \%$ & 0.38 \\
\hline Sacral & $5(1.5 \%)$ & $0.4 \%$ & $4.7 \%$ & 0.005 \\
\hline Gluteus & $3(0.9 \%)$ & $1.2 \%$ & $0 \%$ & 0.30 \\
\hline Histopathological confirmation & $192(58 \%)$ & $61 \%$ & $49.4 \%$ & 0.06 \\
\hline \multicolumn{5}{|l|}{ Morbidity } \\
\hline Diabetes Mellitus & $167(52 \%)$ & $47 \%$ & $64 \%$ & 0.007 \\
\hline Renal impairment & $49(15.2 \%)$ & $10 \%$ & $30 \%$ & 0.001 \\
\hline Coronary Artery disease & $46(14.2 \%)$ & $11 \%$ & $25 \%$ & 0.001 \\
\hline Trauma & $43(15.5 \%)$ & $18.2 \%$ & $8 \%$ & 0.04 \\
\hline Number of debridement ${ }^{b}$ & $2(1-8)$ & $2(1-7)$ & $2(1-8)$ & 0.22 \\
\hline Combined antibiotics(>2) & $94(33.6 \%)$ & $49.3 \%$ & $28.2 \%$ & 0.001 \\
\hline Septic shock & $76(27.8 \%)$ & $19 \%$ & $51.4 \%$ & 0.001 \\
\hline ICU stay in days ${ }^{b}$ & $5.5(1-75)$ & $5(1-43)$ & $9(1-75)$ & 0.002 \\
\hline Hospital stay in days ${ }^{b}$ & $16(2-295)$ & $15(2-295)$ & $20.5(2-273)$ & 0.02 \\
\hline
\end{tabular}

${ }^{*}=$ survivors vs. non-survivors, ${ }^{\text {a }}=$ values in $\left(\right.$ mean $\pm \mathrm{SD}$ ), ${ }^{\mathrm{b}}=$ values in median and (range), $\mathrm{c}=<0.5 \mathrm{ng} / \mathrm{l}$ low risk and $>2.0 \mathrm{ng} / \mathrm{l}$ high risk sepsis 


\section{Laboratory findings}

The initial blood investigations such as hemoglobin, leukocyte count, serum sodium, bilirubin and C-reactive protein were comparable among survivors and nonsurvivors. However, non-survivors had lower levels of hemoglobin ( $10.1 \pm 2.6$ vs. $11.4 \pm 2.7 ; p=0.001)$, platelet count (230 \pm 158 vs. $273 \pm 141 ; p=0.02$ ), blood glucose levels $(10.7 \pm 5.4$ vs. $12.5 \pm 8.4 ; p=0.07)$ and had higher serum creatinine [135 (26-1263) vs. 91 (26-1189); $p=$ $0.001]$ as compared to survivors. The median procalcitonin levels were non-significantly higher in non-survivors [9.8 (0.1-182) vs. $3.3(0.07-303) ; p=0.28]$ than that of survivors. In addition, non-survivors had significantly higher median LRINEC [7 (2-13) vs. $5(1-13) ; p=$ $0.001]$ and SOFA scores [12 (7-21) vs. $9(2-19) ; p=$ 0.001] in comparison to the survivors group. Also, non-survivors were less likely to receive combination of antibiotics (>2 antibiotics) than survivors (28.2\% vs. $49.3 \% ; p=0.001)$.

\section{Microbiological findings}

Table 2 represents the involvement of microorganisms in the pathogenesis of NF. Monobacterial gram positive (42\%) were the most frequent organisms identified followed by polybacterial (34 \%) and monobacterial gram negative (12.5\%). Among gram positive bacteria,

Table 2 Micro-organisms involved in necrotizing fasciitis

\begin{tabular}{lllll}
\hline & Overall & Survivors & Non-survivors & $P$ value \\
\hline Positive wound culture & $204(77 \%)$ & $80.4 \%$ & $67.6 \%$ & 0.03 \\
$\begin{array}{l}\text { Positive blood and } \\
\text { tissue culture }\end{array}$ & $56(21 \%)$ & $18 \%$ & $29.6 \%$ & 0.04 \\
Polybacterial infection & $90(34 \%)$ & $32.5 \%$ & $38.0 \%$ & 0.002 \\
Monobacterial Gram & $111(42 \%)$ & $47.9 \%$ & $25.4 \%$ & for all \\
positive & & & & \\
Monobacterial Gram & $33(12.5 \%)$ & $11.3 \%$ & $15.5 \%$ & \\
negative & & & & \\
Fungal & $30(10.2 \%)$ & $6.9 \%$ & $19.2 \%$ & \\
Gram positive & & & & \\
Streptococcus & $114(38 \%)$ & $42 \%$ & $29 \%$ & 0.05 \\
Staphylococcus & $109(37 \%)$ & $39 \%$ & $29 \%$ & 0.11 \\
Enterococcus & $14(5 \%)$ & $4.5 \%$ & $5.3 \%$ & 0.78 \\
Clostridium & $3(1 \%)$ & $1.4 \%$ & $0 \%$ & 0.30 \\
Gram negative & & & & \\
Bacteroides & $61(22 \%)$ & $20 \%$ & $22.4 \%$ & 0.64 \\
E. Coli & $34(11 \%)$ & $10 \%$ & $16 \%$ & 0.16 \\
Pseudomonas & $23(8 \%)$ & $5.4 \%$ & $14.5 \%$ & 0.01 \\
Klebsiella & $23(8 \%)$ & $6 \%$ & $12 \%$ & 0.12 \\
Aeromonas & $4(1.3 \%)$ & $0.9 \%$ & $2.6 \%$ & 0.26 \\
Proteus & $5(1.7 \%)$ & $0.5 \%$ & $5.3 \%$ & 0.005 \\
Morganella & $2(0.7 \%)$ & $0.5 \%$ & $1.3 \%$ & 0.42 \\
\hline
\end{tabular}

streptococcus (38 \%) and staphylococcus (37 \%) were the most commonly identified organisms. Bacteriodes (22\%) and E-Coli (11 \%) were the predominant gram negative microorganisms. Fungal infection was observed in $30(10.2 \%)$ cases. Among them $22(73.3 \%)$ cases were positive for tissue culture, 7 (23.3\%) were positive for tissue as well as blood culture and one (3.4\%) case was positive for blood culture alone. The frequency of polybacterial (38 \% vs. $32.5 \%, p=0.002)$ and monobacterial gram negative infections ( $15.5 \%$ vs. $11.3 \%, p=0.002)$ were more evident in non-survivors; while monobacterial gram positive organisms were commonly identified among survivors $(47.9 \%$ vs. $25.4 \% ; p=0.002)$ compared to non-survivors.

Pseudomonas (14.5 \% vs. $5.4 \% ; p=0.01)$ and Proteus infections $(5.3 \%$ vs. $0.5 \% ; p=0.005)$ were the most commonly associated microorganisms among nonsurvivors.

\section{Management and outcomes}

The median number of surgical debridements performed was 2 (ranged 1-8) and the hospital length of stay was 16 (2-295) days. The number of debridements was comparable in the 2 groups. The median ICU stay [9 (1-75) vs. 5 days $(1-43) ; p=0.002$ ], overall hospital stay [20.5 $(2-273)$ vs. $15(2-295)$ days; $p=0.02]$ and the frequency of septic shock ( $48 \%$ vs. $20 \%$; $p=0.001$ ) were significantly higher in non-survivors than the survivor group. Recurrent admissions for NF were required for 13 (4 \%) patients; of whom 11 patients were admitted twice and two patients required three admissions. A total of 85 patients died in the present study with an overall mortality rate of $26 \%$. Table 3 shows the major causes of mortality which mainly involved septic shock alone and a combination of bacteremia and multiorgan failure.

Table 4 shows multivariate analysis for the major predictors of mortality. SOFA scoring followed by age were the independent predictors of mortality in the present study cohort. The proportion of mortality based on the bacteriology results is given in Table 5 .

None of the co-morbidities showed significant association with types of microorganisms and combination of antibiotics used except coronary heart disease (CHD). Significantly higher frequency of CHD patients were prescribed more than two antibiotic combinations $(p=$ 0.009). Table 6 compares the co-morbidities with microbiological data and antibiotics used.

\section{Discussion}

The association of high morbidity and mortality in necrotizing fasciitis (NF) patients urges the need for early diagnosis and identification of potential risk factors of worse outcomes. The present study is interestingly large series of NF cases from a Middle Eastern small 
Table 3 Major causes of mortality $(n=85)$ in necrotizing fasciitis patients

\begin{tabular}{ll}
\hline Variable & Number \\
\hline - Septic shock & 22 \\
- Bacteremia \& multiorgan failure & 25 \\
- End stage renal disease and sepsis & 2 \\
- sepsis and Cardiopulmonary arrest & 3 \\
- Disseminated intravascular coagulation and sepsis & 1 \\
- Pulmonary embolism and sepsis & 1 \\
- Acute respiratory distress syndrome & 2 \\
- Stomach cancer and sepsis & 1 \\
- Encephalopathy and sepsis & 1 \\
- Volume overload/HF and sepsis & 1 \\
- Necrotizing pancreatitis + multiorgan failure & 1 \\
- Hypoxic brain injury and sepsis & 1 \\
- Myocardial infarction and sepsis & 1 \\
Septic myocarditis & 1 \\
Cardiac arrest & 3 \\
Cardiogenic shock & 2 \\
Myocardial infarction & 1 \\
Pneumonia & 1 \\
Acute myeloid leukemia and sepsis & 1 \\
\hline
\end{tabular}

population country that assesses various contributing factors to mortality. NF is a fulminant life-threatening infection of the musculoskeletal soft tissues characterized with rapid progression that typically requires urgent surgical interventions [11, 12]. The classic and frequent manifestations associated with NF usually include a triad

Table 4 Multivariate analysis for predictors of mortality

\begin{tabular}{lllll}
\hline & $P$ value & Odd ratio & \multicolumn{2}{c}{$\begin{array}{c}95 \% \text { confidence } \\
\text { interval }\end{array}$} \\
\hline Gender & 0.928 & 0.952 & 0.328 & 2.762 \\
Age & 0.001 & 1.06 & 1.03 & 1.11 \\
Serum hemoglobin & 0.416 & 1.088 & 0.888 & 1.333 \\
Serum sodium & 0.442 & 0.965 & 0.883 & 1.056 \\
Serum glucose & 0.887 & 0.995 & 0.926 & 1.069 \\
Serum creatinine & 0.557 & 0.999 & 0.997 & 1.002 \\
SOFA score & 0.020 & 1.23 & 1.03 & 1.49 \\
Lower Limb NF & 0.979 & 1.017 & 0.278 & 3.719 \\
Perineum NF & 0.891 & 1.096 & 0.296 & 4.059 \\
Abdominal NF & 0.671 & 1.496 & 0.234 & 9.574 \\
Prior coronary artery disease & 0.917 & 1.060 & 0.355 & 3.162 \\
Monobacterial Gram positive & 0.086 & 0.435 & 0.168 & 1.124 \\
\hline
\end{tabular}

NF necrotizing fasciitis
Table $\mathbf{5}$ Mortality based on the bacteriology results

\begin{tabular}{lll}
\hline & Number of cases & Mortality \\
\hline Polybacterial infection & 90 & $27(38 \%)$ \\
Gram Positive alone & 111 & $18(25.4 \%)$ \\
Gram negative alone & 33 & $11(15.5 \%)$ \\
Fungal $^{\text {a }}$ & 30 & $15(21.1 \%)$ \\
Total $^{\text {b }}$ & 265 & 71 \\
a $^{\text {overlap with Gram stain bacteria, }}{ }^{\text {b }}$ Confirmed results
\end{tabular}

of pain, tender local swelling, and fever [13, 14]. Consistent with earlier reports, this triad was more frequently observed among survivors in the current series. Moreover, out of proportion pain on physical examination and unresolved cellulitis are major diagnostic clues for $\mathrm{NF}$, however, these clinical features often appear later in the disease course [9]. Therefore, delayed diagnosis is usually associated with high mortality (up to $25 \%$ ) among young adults which could even reach $44 \%$ in elderly population $[9,15]$. The number of in-hospital deaths in the present study is $26 \%$ which is consistent with earlier studies.

The current literature suggests that NF could occur at any age but is mostly reported within the age range of 32 to 57 years $[16,17]$. In the present study, the mean age was 51 years and the non-survivors were 14.5 years older than the survivors at the time of presentation. The reason of the frequently observed association of NF with advanced age could be explained in part by the preexisting co-morbidities and immunosuppression. In this context, Golger et al. [18] reported advanced age, streptococcal toxic shock syndrome and immunocompromised status to be independent predictors of mortality in NF patients.

The frequently associated co-morbidities in NF are diabetes mellitus, malignancy, chronic cardiac disease, peripheral vascular disease, chronic renal disease, and immune-suppression [19]. Other predisposing factors include traumatic injuries, smoking, history of muscular injection and paraplegia. Diabetes mellitus, hypertension, and renal impairment were the most frequent comorbidities associated with mortality in the current series. Diabetes mellitus remains the main co-morbidity in NF patients which is associated with prolonged hospitalization and increased mortality $[13,20]$. In this study, patients with a history of diabetes mellitus showed considerably rapid progress of the severity of NF and mortality. This finding could be attributed in part to the hyperglycemic status that compromises the immunity status and fosters bacterial growth. However, the initial readings of serum sugar in the study cohort were nonsignificantly lower in non-survivors. Unfortunately, the current database did not include HbA1c to explain inpart this finding. The other common comorbidity in the 
Table 6 Comparison of co-morbidities with microbiological data and antibiotics

\begin{tabular}{lllll}
\hline & Diabetes mellitus $(n=167)$ & Renal impairment $(n=49)$ & Coronary artery disease $(n=46)$ & Trauma $(n=43)$ \\
\hline Polybacterial infection & $51(30.5 \%)$ & $14(28.6 \%)$ & $10(21.7 \%)$ & $18(41.9 \%)$ \\
Monobacterial Gram positive & $54(32.3 \%)$ & $12(24.5 \%)$ & $11(23.9 \%)$ & $16(37.2 \%)$ \\
Monobacterial Gram negative & $19(11.4 \%)$ & $7(14.3 \%)$ & $6(13.0 \%)$ & $0(0.0 \%)$ \\
Fungal & $21(12.6 \%)$ & $9(18.4 \%)$ & $7(15.2 \%)$ & $2(4.6 \%)$ \\
Antibiotic combination used $(>2)$ & $47(28.1 \%)$ & $18(36.7 \%)$ & $21(45.6 \%)^{a}$ & $13(30.2 \%)$ \\
\hline
\end{tabular}

a statistically significant

present study was hypertension, which might cause disruption of the microvascular supply and reduction of tissue oxygenation and antimicrobial delivery. The frequency of hypertension was significantly higher in the non-survivors group. Consistently, Huang et al. [8] demonstrated a high association of hypertension among NF non-survivors. Earlier studies have also outlined the increased risk of NF in the presence of the abovementioned pathologies [21, 22]. Furthermore, elderly patients with such co-morbidities who are suspected to have NF should be evaluated thoroughly to rule out NF, even in the absence of the usual hard manifestations.

Although, NF might affect any part of the body, earlier studies have reported frequent involvement of the extremities, perineum, head \& neck and truncal regions [23]. In the current series, the most frequent sites of infection included lower limbs, perineum, abdominal/ groin and neck/facial regions. The site of infection and its expansion also affect mortality. It has been suggested that affection of the head and neck region is associated with higher mortality as accounted for the proximity with various vital anatomical structures [24]. Mao et al. [25] analyzed the craniocervical NF cases with and without thoracic extension and observed a poor survival with thoracic extension as compared to non-thoracic extension. An earlier study reported a lower rate of mortality in extremity infection in comparison to abdominal and perineal infections [26]. Urschel [27] suggested that NF infection extending proximally to pelvis or trunk might have worse prognosis. Therefore, early and aggressive treatment aimed at restriction of the infection with repeated surgical debridement could be useful in achieving better survival rates.

Unfortunately, the first stage of NF disease is frequently masked by non-specific manifestations, which prevents effective and timely specific therapy [28]. Therefore, early identification and diagnosis is mandatory and should not rely only on the clinical signs alone [6]. Consequently, prognostic indicators such as laboratory markers and specific patient characteristics obtained from the medical history would assist in the early diagnosis, risk stratification and decision making [29]. Earlier studies identified some laboratory findings such as anemia, elevated creatinine, and increased white cell count to be non-specifically associated with NF which might affect prognosis. In the present series, non-survivors had significantly lower levels of hemoglobin and platelet count and had higher serum creatinine as compared to survivors. Similarly, an earlier study observed that non-survivors had significantly lower levels of hemoglobin and platelet and presented with higher levels of serum glucose and creatinine than the survivors [8]. An earlier study reported that aeromonas infection, advanced age, band PMNs $>10 \%$, serum creatinine $(>2.0 \mathrm{mg} / \mathrm{dL})$, and an activated prothrombin time ( $>60 \mathrm{~s}$ ) were found to be the independent predictors of mortality in NF patients [8]. In the present study the major predictors of mortality were age and SOFA scoring. SOFA score is a useful tool to assess the severity of NF based on the involvement of major organ systems. In the present series, non-survivors had significantly higher median SOFA scores which are in accordance with the current literature. The initial increase in SOFA score during the first two days of ICU admission successfully predicts high rates of mortality (50-95\%) [30]. This finding could be used as an alarming indictor and encourages physicians to refer those patients as early as possible to the tertiary care centers for the appropriate intensive care. Therefore, the use of validated prognostic factors in daily clinical practice, especially for initial diagnosis in emergency departments, would help physicians for timely management and obtaining better outcomes.

It has been suggested that bacteremia is one of the frequent complications of NF which has been associated with higher risk of mortality [31]. In the current study, $21 \%$ of the patients had positive blood and tissue cultures and subsequently had higher mortality rate in comparison to those who had negative blood culture. Similarly, Huang et al. [8] observed four-fold increased rate of mortality in patients with positive blood cultures than those who had negative cultures.

Consistent with previous reports [13], gram positive microorganisms, mainly streptococcus and staphylococcus organism, were frequently identified in the present study cohort. On the other side, bacteriodes and E-coli were the predominant gram negative organisms. In the present study, monobacterial infections with pseudomonas and proteus were the most commonly associated microorganisms among non-survivors. However, earlier 
Table 7 Summary of published studies of mortality in necrotizing fasciitis/NSTI patients worldwide

\begin{tabular}{|c|c|c|c|c|}
\hline Authors & Year/country & Study type/duration & Mortality & Predictors of mortality \\
\hline Dahm P et al. [40] & 2000/USA & $\begin{array}{l}\text { Retrospective/1984 } \\
\text { to } 1998\end{array}$ & $\begin{array}{l}\text { Overall mortality rate } \\
\text { was } 20 \%(10 / 50)\end{array}$ & $\begin{array}{l}\text { The extent of the infection }(P=0.0234) \text { was } \\
\text { the only significant, independent predictor } \\
\text { of outcome }\end{array}$ \\
\hline Chin-Ho Wong et al. [29] & 2003/Singapore & $\begin{array}{l}\text { Retrospective/1997 } \\
\text { to } 2002\end{array}$ & Total $n=89$ & $\begin{array}{l}\text { A delay in surgery of }>24 \mathrm{~h} \text { was correlated } \\
\text { with increased mortality }(p<0.05 ; \mathrm{RR}=9.4)\end{array}$ \\
\hline Daniel A. Anaya et al. [32] & 2005/USA & $\begin{array}{l}\text { Retrospective/1996 } \\
\text { to } 2001\end{array}$ & $\begin{array}{l}\text { The overall mortality } \\
\text { rate was } 16.9 \% \text { (total } \\
n=166 \text { ) }\end{array}$ & $\begin{array}{l}\text { Independent predictors of mortality included } \\
\text { WBC }>30000 \times 103 / \mu \mathrm{L} \text {, creatinine level }> \\
2 \mathrm{mg} / \mathrm{dL}(176.8 \mu \mathrm{mol} / \mathrm{L}) \text {, and heart disease at } \\
\text { hospital admission }\end{array}$ \\
\hline Kwan MK et al. [41] & 2006/Malaysia & $\begin{array}{l}\text { Retrospective/1998 } \\
\text { to } 2002\end{array}$ & $\begin{array}{l}\text { Overall mortality rate } \\
\text { was } 36 \% \text { (total } n=36 \text { ) }\end{array}$ & $\begin{array}{l}\text { A poor WBC response, high serum urea and } \\
\text { creatinine, and low haemoglobin level were } \\
\text { the predictors for mortality }\end{array}$ \\
\hline Golger A et al. [18] & 2007/Canada & $\begin{array}{l}\text { Retrospective/1994 } \\
\text { to } 2001\end{array}$ & $\begin{array}{l}\text { Ninety-nine patients } \\
\text { satisfied the inclusion } \\
\text { criteria. Overall mortality } \\
\text { was } 20 \%\end{array}$ & $\begin{array}{l}\text { Advanced age }(\mathrm{OR}, 1.04 ; 95 \% \mathrm{Cl}, 1.01 \text { to } 1.08 \text {; } \\
p=0.012), \text { streptococcal toxic shock syndrome } \\
(\mathrm{OR}, 10.54 ; 95 \% \mathrm{Cl}, 2.80 \text { to } 39.44 ; p<0.001) \text {, } \\
\text { and immunocompromised status (OR, 3.97; } \\
95 \% \mathrm{Cl}, 1.04 \text { to } 15.19 ; p=0.044) \text { were } \\
\text { independent predictors of mortality }\end{array}$ \\
\hline
\end{tabular}

Mulla ZD et al. [42] 2007/USA_ Case series/2001

Hsiao CT et al. [9] 2008/Taiwan

Bair MJ et al. [43]

2009/Taiwan

Kao LS et al. [45]

2011/USA

Huang KF et al. [8]

2011/Taiwan

Yeung YK et al. [46]

2011/Hong Kong

Nisbet $M$ et al. [47]

2011/New Zealand

Krieg et al. [48]
2014/Germany
Retrospective/1995 to 2006

Retrospective/2000 to 2007

Retrospective/2003 to 2009

Retrospective/2004 to 2007

Retrospective

Retrospective/2000 to 2006

The crude hospital mortality rate was $11.1 \%$ (total $n=216$ )

${ }^{\mathrm{a}} 24 / 128(19 \%)$

The overall mortality was $17.0 \%$. total $n=85$

24/119 (20\%)

Mortality rates varied between 6 hospitals from $9 \%$ to $25 \%$ ( $n=296)$

Overall mortality was $12.1 \%(n=57 / 472)$ and the 30 day mortality was $11.0 \%(n=52 / 472)$

Overall mortality was $28 \%$ (total $n=29$ )

Twenty-five (30\%) patients died, 17 (68\%) within 72 h of admission. Total $n=82$

Retrospective/1996 ${ }^{\mathrm{a}}$ 24/64(32.8\%) to 2011
Patients aged $>$ or $=44$ years at the time of admission were 5 times as likely to die in the hospital than patients who were aged $<$ or $=43$ years (adjusted RR 5.08, $P=0.03$ )

Aeromonas infection, Vibrio infection, cancer, hypotension, and band form WBC > $10 \%$ were independent positive predictors of mortality $(P<0.05)$. Presence of hemorrhagic bullae was a negative predictor of mortality $(P<0.05)$

Predictors of mortality included advanced age, class C liver cirrhosis, ascites, higher serum creatinine, and lower hemoglobin and platelet levels

The presence of hemorrhagic bullous skin lesions/necrotizing fasciitis, primary septicemia, a greater severity of illness, absence of leukocytosis, and hypoalbuminemia were the significant risk factors for mortality

Patient age and severity of disease (reflected by shock requiring vasopressors and renal failure postoperatively) were the main predictors of mortality

Eight independent predictors of mortality : liver cirrhosis, soft tissue air, Aeromonas infection, age $>60$ years, band polymorphonuclear neutrophils $>10 \%$, activated partial thromboplastin time $>60 \mathrm{~s}$, bacteremia, and serum creatinine $>2 \mathrm{mg} / \mathrm{dL}$

Renal and liver failure, thrombocytopenia, initial proximal involvement, and hypotension on admission were predictors of mortality in UL NF. The ALERTS (Abnormal Liver function, Extent of infection, Renal impairment, Thrombocytopenia, and Shock) score with a cutoff of 3 appeared to predict mortality.

Independent predictors of mortality include congestive heart failure $(P=0.033)$ and a history of gout $(P=0.037)$

Independent predictors of mortality were skin necrosis on the initial clinical examination $(\mathrm{OR}=15.48 ; 95 \% \mathrm{Cl}=2.02$ $118.91)$ and acute renal failure $(\mathrm{OR}=118.91 ; 95 \% \mathrm{Cl} 7.66-5135.79)$ 
Table 7 Summary of published studies of mortality in necrotizing fasciitis/NSTI patients worldwide (Continued)

\begin{tabular}{|c|c|c|c|c|}
\hline Lee YC et al. [49] & 2014/Taiwan & $\begin{array}{l}\text { Retrospective/1996 } \\
\text { to } 2011\end{array}$ & 18/100 (18 \%) & $\begin{array}{l}\text { Unknown injury events, presence of multiple } \\
\text { skin lesions, leukocytes }<10,000 \text { cells } / \mathrm{mm}^{3} \text {, } \\
\text { platelets }<100,000 / \mathrm{mm}^{3} \text {, serum creatinine } \\
\geq 1.3 \mathrm{mg} / \mathrm{dL} \text {, serum albumin }<2.5 \mathrm{mg} / \mathrm{dL} \text {, } \\
\text { and delayed treatment beyond } 3 \text { days } \\
\text { post-injury were associated with significantly } \\
\text { higher mortality. } \\
\text { Treatment delayed beyond } 3 \text { days is an } \\
\text { independent factor indicating a poor } \\
\text { prognosis (OR } 10.75,95 \% \mathrm{Cl} 1.02-113.39 \text {, } \\
p=0.048 \text { ) }\end{array}$ \\
\hline Khamnuan P et al. [50] & 2015/Thailand & $\begin{array}{l}\text { Retrospective/2009 } \\
\text { to } 2012\end{array}$ & $n=290 / 1504(19.3 \%)$ & $\begin{array}{l}\text { Female gender; age }>60 \text {; chronic heart } \\
\text { disease, cirrhosis, skin necrosis, pulse rate } \\
>130 / \mathrm{min} \text {, systolic BP }<90 \mathrm{mmHg} \text {, and serum } \\
\text { creatinine } \geq 1.6 \mathrm{mg} / \mathrm{dL}\end{array}$ \\
\hline Khamnuan P et al. [51] & 2015/Thailand & $\begin{array}{l}\text { Retrospective } \\
\text { observational cohort } \\
\text { study/2009 to } 2012\end{array}$ & $\begin{array}{l}165(69.6) \text { in patients with } \\
\text { severe sepsis }(n=237) \\
66(5.5) \text { without severe } \\
\text { sepsis }(n=1,215) \\
P<0.001\end{array}$ & $\begin{array}{l}\text { Female sex, diabetes mellitus, chronic heart } \\
\text { disease, hemorrhagic bleb, skin necrosis, and } \\
\text { serum protein }<6 \mathrm{~g} / \mathrm{dL}\end{array}$ \\
\hline Arif et al. [52] & 2016/USA & $\begin{array}{l}\text { Retrospective/2003 } \\
\text { to } 2013\end{array}$ & $\begin{array}{l}9871 \text { NF-related deaths } \\
4 \cdot 8 \text { deaths/ } \\
1000000 \text { person-yr }\end{array}$ & $\begin{array}{l}\text { Diabetes mellitus, obesity, and renal failure } \\
\text { were significantly associated with NF-related } \\
\text { death. However, age, sex, and race were } \\
\text { independently associated with the rate of } \\
\text { NF-related deaths }\end{array}$ \\
\hline Hadeed GJ et al. [35] & 2016/USA & $\begin{array}{l}\text { Retrospective/2003 } \\
\text { to } 2008\end{array}$ & 11/87 (12.5 \%) & $\begin{array}{l}\text { Clinically significant difference based on the } \\
\text { timing of surgical intervention }(<\text { or }>6 \mathrm{~h}) \\
\text { ( } 17.5 \% \text { in late vs. } 7.5 \% \text { in early intervention } \\
\text { group), however no statistical significance }\end{array}$ \\
\hline
\end{tabular}

$\mathrm{a}=$ Deaths/total NF cases

studies reported clostridial [32], beta-streptococci [33], aeromonas and vibrio [9] infections to be associated with poor outcomes.

Prompt and aggressive debridement is important for the management of NF. The debridement aims to remove all necrotic tissue until the local infectious process is treated. There is a positive correlation between the survival rate and early diagnosis with appropriate surgical debridement in NF patients [34]. In the present study, the median number of debridement procedures performed per patient was two interventions, and these were comparable for both non-survivors as well as survivors. Data suggested that early surgical intervention is crucial in reducing morbidity and mortality in NF patients [35]. However, there is still a lack of clear definition on 'How early should we be'. Kobayashi et al. showed significantly lower mortality in the early intervention group (within $12 \mathrm{~h}$ after diagnosis) [36]. Delay of surgical treatment of $>12 \mathrm{~h}$ was associated with an increased number of surgical debridement, septic shock and acute renal failure [36]. Hadeed et al. [35] reported outcomes of earlier surgical treatment (within the first $6 \mathrm{~h}$ ) and found that although there was no statistically significantly difference in mortality between the study groups, higher mortality among late intervention group was clinically significant. Moreover, the outcomes in terms of the duration of hospital and intensive care unit stay were in favor of early intervention [35].

The appropriate and early antibiotic use and intensive care measures significantly appear to affect patients' outcomes. In the past decades, patients with NF have higher mortality rates (up to $70 \%$ ), however, currently with improved surgical and intensive care treatment, mortality rates have declined to less than $30 \%[37,38]$. Not only delayed diagnosis and surgical intervention influences in-hospital mortality, but also, the development of secondary complications has unfavorable impact [39]. The major complications that significantly related to mortality in the present series were bacteremia, septic shock and multiorgan failure. Therefore, appropriate prevention and management of such complications are vital for improving the outcome in these vulnerable patients [39].

Table 7 summarizes the published studies of mortality in NF and NSTI worldwide between 2000 and 2016. There is no consensus for specific predictors of mortality between these 20 studies including the current study. The design and objectives of studies as well as the availability of clinical and laboratory data are the main reason of the diversity of predictors of mortality among these studies. The present study has several limitations. It is retrospective in nature. It lacks information regarding the exact time of commencing antibiotics, delay in diagnosis, the timing of surgical debridement and the type of 
surgery performed post diagnosis. Also, the sensitivity and minimum inhibitory concentration of the bacteria and percentage of multi drug resistant strains is not available . Data describing the empiric antibiotic treatment in the emergency room is also not available for analysis. Moreover, procalcitonin has been introduced recently at $\mathrm{HGH}$; therefore not all the NF in the past underwent procalcitonin assessment at admission. Further prospective studies are required to determine the time interval between the diagnosis and treatment which could possibly influence the mortality among NF patients.

\section{Conclusion}

The mortality rate is quite high as one quarter of NF patients died in the hospital. The present study highlights the clinical characteristics and predictors of mortality in NF patients. It is important to have a high index of suspicion at initial presentation. Use of prognostic tools in the daily clinical practice will help physicians for the proper on-time management. The present study provides useful information on the severity and outcome of $\mathrm{NF}$ patients that will inform institutional guidelines for the on-time treatment of NF.

\section{Abbreviations \\ CRP, C-reactive protein; LRINEC, laboratory risk indicator for necrotizing fasciitis score; MAP, mean arterial pressure; NF, necrotizing fasciitis; NSAID, non-steroidal anti-inflammatory drug; SOFA, sequential organ failure assessment.}

\section{Acknowledgement}

We thank all the surgical intensive care unit staff, Hamad General Hospital, Doha, Qatar. All the authors have read and approved the manuscript, and all have no financial issue to disclose.

\section{Funding}

This research did not receive any specific grant from any funding agency in the public, commercial or not-for-profit sector.

\section{Availability of data and materials}

Data supporting the present findings can be obtained, if needed, after getting permission from the medical research center (MRC) at HMC (research@hamad.qa). A waiver of consent (IRB \# 14066/14) was granted for this study from MRC as there was no direct contact with patients and all data were retrieved retrospectively under full confidentiality to protect patients' privacy.

\section{Authors' contributions}

GJ: acquisition of data, writing manuscript and review of manuscript; AE: conception and design of the study, interpretation of data, writing manuscript and critical review of manuscript; RP: study design, helped to draft manuscript and review of manuscript; NS: acquisition of data, writing manuscript and critical review of manuscript; HA: study design, acquisition of data and critical review of manuscript; INM: acquisition of data, writing manuscript and review of manuscript; ME: acquisition of data, writing manuscript and critical review of manuscript; HA: conception and design of the study, writing manuscript and critical review of manuscript. All authors read and approved the final manuscript.

\section{Competing interests}

The authors declare that they have no competing interests.
Consent for publication

Not applicable.

\section{Ethics approval and consent to participate}

Ethical approval was obtained from the Medical Research Center (IRB\# 14066/14) and waiver consent was approved for this retrospective study by the Hamad Medical Corporation, Doha, Qatar.

\section{Author details}

'Department of Surgery, Hamad General Hospital (HGH), Doha, Qatar. ${ }^{2}$ Clinical Research, Trauma Surgery, Hamad General Hospital, Doha, Qatar ${ }^{3}$ Clinical Medicine, Weill Cornell Medical School, Doha, Qatar. ${ }^{4}$ Trauma Surgery Section, Hamad General Hospital, Doha, Qatar. ${ }^{5}$ Surgical Intensive Care Unit, HGH, Doha, Qatar.

Received: 24 May 2016 Accepted: 2 August 2016

Published online: 08 August 2016

\section{References}

1. Puvanendran R, Huey JC, Pasupathy S. Necrotizing fasciitis. Can Fam Physician. 2009;55:981-7.

2. Yaghubiian A, de Virgillio C, Dauphine C, Lewis RJ, Mathew L. Use of Admission Serum Lactate and Sodium Levels to Predict Mortality in Necrotizing Soft-Tissue Infections. Arch Surg. 2007;142:840-6.

3. Roje Z, Roje Z, Matić D, Librenjak D, Dokuzović S, Varvodić J. Necrotizing fasciitis: literature review of contemporary strategies for diagnosing and management with three case reports: torso, abdominal wall, upper and lower limbs. World J Emerg Surg. 2011;6:46. doi:10.1186/1749-7922-6-46.

4. Magala J, Makobore P, Makumbi T, Kaggwa S, Kalanzi E, Galukande M. The clinical presentation and early outcomes of necrotizing fasciitis in a Ugandan Tertiary Hospital- a prospective study. BMC Research Notes. 2014; 7:476. doi:10.1186/1756-0500-7-476.

5. Kalaivani V, Hiremath BV, Indumathi VA. Necrotising Soft Tissue InfectionRisk Factors for Mortality. J ClinDiagn Res. 2013;7:1662-5.

6. Wall DB, Klein SR, Black S, de Virgilio C. A simple model to help distinguish necrotizing fasciitis from nonnecrotizing soft tissue infection. J Am Collsurg. 2000;191:227-31.

7. Wong CH, Khin LW, Heng KS, Tan KC, Low CO. The LRINEC (laboratory risk indicator for necrotizing fasciitis) score: a tool for distinguishing necrotizing fasciitis from other soft tissue infections. Crit Care Med. 2004;32:1535-41.

8. Huang KF, Hung MH, Lin YS, Lu CL, Liu C, Chen CC, et al. Independent predictors of mortality for necrotizing fasciitis: a retrospective analysis in a single institution. J Trauma. 2011;71:467-73.

9. Hsiao CT, Weng HH, Yuan YD, Chen CT, Chen IC. Predictors of mortality in patients with necrotizing fasciitis. Am J Emerg Med. 2008;26:170-5.

10. Vincent JL, Moreno R, Takala J, Willatts S, De Mendonça A, Bruining H, et al. The SOFA (Sepsis-related Organ Failure Assessment) score to describe organ dysfunction/failure. On behalf of the Working Group on Sepsis-Related Problems of the European Society of Intensive Care Medicine. Intensive Care Med. 1996;22:707-10

11. Majeski J, Majeski E. Necrotizing fasciitis: improved survival with early recognition by tissue biopsy and aggressive surgical treatment. South Med J. 1997;90:1065-8.

12. Gunter OL, Guillamondegui OD, May AK, Diaz JJ. Outcome of necrotizing skin and soft tissue infections. Surg Infect (Larchmt). 2008;9:443-50.

13. Wang JM, Lim HK. Necrotizing fasciitis: eight-year experience and literature review. Braz J Infect Dis. 2014;18:137-43.

14. Dworkin MS, Westercamp MD, Park L, McIntyre A. The epidemiology of necrotizing fasciitis including factors associated with death and amputation. Epidemiol Infect. 2009;137:1609-14.

15. Elliot DC, Kufera JA, Myers RA. Necrotizing soft tissue infections: risk factors for mortality and strategies for management. Ann Surg. 1996;224:672-83.

16. McHenry CR, Piotrowski JJ, Malangoni MA. Determinants of mortality for necrotizing soft tissue infection. Ann Surg. 1995;221:558-65.

17. Lille ST, Sato TT, Engrav LH, Foy H, Jurkovich GJ. Necrotizing soft tissue infections: obstacles in diagnosis. J Am CollSurg. 1996;182:7-11.

18. Golger A, Ching S, Goldsmith CH, Pennie RA, Bain JR. Mortality in patients with necrotizing fasciitis. PlastReconstr Surg. 2007;119:1803-7.

19. Goh T, Goh LG, Ang CH, Wong CH. Early diagnosis of necrotizing fasciitis. Br JSurg. 2014;101:e119-25. doi:10.1002/bjs.9371. 
20. Alva AM, Talwalkar SC, Shah N, Lee N. Necrotising fasciitis: a series of seven cases. Acta Orthop Belg. 2013;79:104-6.

21. Kao LS, Knight MT, Lally KP, Mercer DW. The impact of diabetes in patients withnecrotizing soft tissue infections. Surg Infect (Larchmt). 2005;6:427-38.

22. Cuschieri J. Necrotizing soft tissue infection. Surg Infect (Larchmt). 2008;9: 559-62.

23. Hasham S, Matteucci P, Stanley PR, Hart NB. Necrotising fasciitis. BMJ. 2005; 330:830-3.

24. Shaariyah MM, Marina MB, Razif MYM, Mazita A, Primuharsa Putra SHA Necrotizing fasciitis of the head and neck: surgical outcomes in three cases. Malays J Med Sci. 2010;17:51-5

25. Mao JC, Carron MA, Fountain KR, Stachler RJ, Yoo GH, Mathog RH, et al. Craniocervical necrotizing fasciitis with and without thoracic extension: management strategies and outcome. Am J Otolaryngol. 2009;30:17-23.

26. Pessa ME, Howard RJ. Necrotizing fasciitis. SurgGynecol Obstet. 1985;161: 357-61.

27. Urschel JD. Necrotizing soft tissue infections. Postgrad Med J. 1999;75:645-9.

28. Callahan TE, Schecter WP, Horn JK. Necrotizing soft tissue infection masquerading ascutaneous abcess following illicit drug injection. Arch Surg. 1998;133:812-7.

29. Wong $\mathrm{CH}$, Chang HC, Pasupathy S, Khin LW, Tan JL, Low CO. Necrotizing fasciitis: clinical presentation, microbiology, and determinants of mortality. J Bone Joint Surg Am. 2003;85:1454-60.

30. Vosylius S, Sipylaite J, Ivaskevicius J. Sequential organ failure assessment score as the determinant of outcome for patients with severe sepsis. Croat Med J. 2004;45:715-20

31. Elliott DC, Kufera JA, Myers RA. Necrotizing soft tissue infections. Risk factors for mortality and strategies for management. Ann Surg. 1996;224:672-83.

32. Anaya DA, McMahon $K$, Nathens AB, Sullivan SR, Foy H, Bulger E. Predictors of mortality and limb loss in necrotizing soft tissue infections. Arch Surg. 2005;140:151-7.

33. Childers BJ, Potyondy LD, Nachreiner R, Rogers FR, Childers ER, Oberg KC, et al. Necrotizing fasciitis: a fourteen-year retrospective study of 163 consecutive patients. Am Surg. 2002;68:109-16.

34. Wong $\mathrm{CH}$, Yam AK, Tan AB, Song C. Approach to debridement in necrotizing fasciitis. Am J Surg. 2008;196:e19-24. doi:10.1016/j.amjsurg.2007. 08.076.

35. Hadeed GJ, Smith J, O'Keeffe T, Kulvatunyou N, Wynne JL, Joseph B, et al. Early Surgical Intervention And Its Impact On Patients Presenting With Necrotizing Soft Tissue Infections: A Single Academic Centre Experience. J Emerg Trauma Shock. 2016;9(1):22-7.

36. Kobayashi L, Konstantinidis A, Shackelford S, Chan LS, Talving P, Inaba K, Demetriades D. Necrotizing soft tissue infections: delayed surgical treatment is associated with increased number of surgical debridements and morbidity. J Trauma. 2011;71(5):1400-5.

37. Yilmazlar T, Ozturk E, Alsoy A, Ozguc H. Necrotizing soft tissue infections: APACHE II score, dissemination, and survival. World J Surg. 2007;31:1858-62.

38. Lee TC, Carrick MM, Scott BG, Hodges JC, Pham HQ. Incidence and clinical characteristics of methicillin-resistant Staphylococcus aureus necrotizing fasciitis in a large urban hospital. Am J Surg. 2007;194:809-12.

39. Yu C-M, Huang W-C, Tung K-Y, Hsiao H-T. Necrotizing Fasciitis Risk Factors in Elderly Taiwan Patients. Int J Gerontology. 2011;5:41-4. doi:10.1016/j.ijge. 2011.01.007.

40. Dahm P, Roland FH, Vaslef SN, Moon RE, Price DT, Georgiade GS, Vieweg J. Outcome analysis in patients with primary necrotizing fasciitis of the male genitalia. Urology. 2000;56(1):31-5. discussion 35-6.

41. Kwan MK, Saw A, Chee EK, Lee CS, Lim CH, Zulkifle NA, Saarey NH, Mohamad Hussien MN. Necrotizing fasciitis of the lower limb: an outcome study of surgical treatment. Med J Malaysia. 2006;61(Suppl A):17-20.

42. Mulla ZD, Gibbs SG, Aronoff DM. Correlates of length of stay, cost of care, and mortality among patients hospitalized for necrotizing fasciitis. Epidemiol Infect. 2007;135(5):868-76. Epub 2006 Nov 3

43. Bair MJ, Chi H, Wang WS, Hsiao YC, Chiang RA, Chang KY. Necrotizing fasciitis in southeast Taiwan: clinical features, microbiology, and prognosis. Int J Infect Dis. 2009;13(2):255-60. doi:10.1016/j.jiji.2008.04.015. Epub 2008 Oct 15.

44. Kuo Chou TN, Chao WN, Yang C, Wong RH, Ueng KC, Chen SC. Predictors of mortality in skin and soft-tissue infections caused by Vibrio vulnificus. World J Surg. 2010;34(7):1669-75. doi:10.1007/s00268-010-0455-y.
45. Kao LS, Lew DF, Arab SN, Todd SR, Awad SS, Carrick MM, Corneille MG, Lally KP. Local variations in the epidemiology, microbiology, and outcome of necrotizing soft-tissue infections: a multicenter study. Am J Surg. 2011; 202(2):139-45. doi:10.1016/j.amjsurg.2010.07.041. Epub 2011 May 4.

46. Yeung YK, Ho ST, Yen CH, Ho PC, Tse WL, Lau YK, Choi KY, Choi ST, Lam MM, Cheng SH, Wong TC. Factors affecting mortality in Hong Kong patients with upper limb necrotising fasciitis; Hong Kong Society for Surgery of the Hand. Hong Kong Med J. 2011;17(2):96-104.

47. Nisbet M, Ansell G, Lang S, Taylor S, Dzendrowskyj P, Holland D. Necrotizing fasciitis: review of 82 cases in South Auckland. Intern Med J. 2011;41(:543-8. doi:10.1111/j.1445-5994.2009.02137.x. Epub 2009 Dec 4.

48. Krieg A, Dizdar L, Verde PE, Knoefel WT. Langenbecks. Predictors of mortality for necrotizing soft-tissue infections: a retrospective analysis of 64 cases. Arch Surg. 2014;399(3):333-41. doi:10.1007/s00423-014-1162-1. Epub 2014 Jan 11.

49. Lee YC, Hor LI, Chiu HY, Lee JW, Shieh SJ. Prognostic factor of mortality and its clinical implications in patients with necrotizing fasciitis caused by Vibrio vulnificus. Eur J Clin Microbiol Infect Dis. 2014;33(6):1011-8. doi:10.1007/s10096-013-2039-x. Epub 2014 Jan 14.

50. Khamnuan P, Chongruksut W, Jearwattanakanok K, Patumanond J, Yodluangfun S, Tantraworasin A. Necrotizing fasciitis: risk factors of mortality. Risk Manag Healthc Policy. 2015:8:1-7. doi:10.2147/RMHP.S77691. eCollection 2015.

51. Khamnuan P, Chongruksut W, Jearwattanakanok K, Patumanond J, Tantraworasin A. Clinical predictors for severe sepsis in patients with necrotizing fasciitis: an observational cohort study in northern Thailand. Infect Drug Resist. 2015;8:207-16. doi:10.2147/IDR.S85249. eCollection 2015.

52. Arif N, Yousfi S, Vinnard C. Deaths from necrotizing fasciitis in the United States, 2003-2013. Epidemiol Infect. 2016;144(6):1338-44.

\section{Submit your next manuscript to BioMed Central and we will help you at every step:}

- We accept pre-submission inquiries

- Our selector tool helps you to find the most relevant journal

- We provide round the clock customer support

- Convenient online submission

- Thorough peer review

- Inclusion in PubMed and all major indexing services

- Maximum visibility for your research

Submit your manuscript at www biomedcentral.com/submit
C BioMed Central 